Editorial

\title{
An Interview with Frieder Nake
}

\author{
Glenn W. Smith
}

Space Machines Corporation, 3443 Esplanade Ave., Suite 438, New Orleans, LA 70119, USA;

gsmith@space-machines.com

Received: 24 May 2019; Accepted: 26 May 2019; Published: 31 May 2019

check for

updates

\begin{abstract}
In this interview, mathematician and computer art pioneer Frieder Nake addresses the emergence of the algorithm as central to our understanding of art: just as the craft of computer programming has been irreplaceable for us in appreciating the marvels of the DNA genetic code, so too has computer-generated art-and with the algorithm as its operative principle-forever illuminated its practice by traditional artists.
\end{abstract}

Keywords: algorithm; computer art; emergent phenomenon; Paul Klee; Frieder Nake; neural network; DNN; CNN; GAN

\section{Introduction}

The idea that most art is to some extent algorithmic, ${ }^{1}$ whether produced by an actual computer or a human artist, may well represent the central theme of the Arts Special Issue "The Machine as Artist (for the 21st Century)" as it has evolved in the light of more than fifteen thoughtful contributions. This, in turn, brings forcibly to mind mathematician, computer scientist, and computer art pioneer Frieder Nake, one of a handful of pioneer artist-theorists who, for more than fifty years, have focused on algorithmic art per se, but who can also speak to the larger role of the algorithm within art.

As a graduate student in mathematics at the University of Stuttgart in the mid-1960s (and from which he graduated with a PhD in Probability Theory in 1967), Nake was a core member, along with Siemens mathematician and philosophy graduate student Georg Nees, of the informal "Stuttgart School", whose leader was philosophy professor Max Bense-one of the first academics to apply information processing principles to aesthetics. Indeed, Bense's lecture halls were the site, in early 1965, of the world's very first exhibition of computer-generated art: a dozen or so abstract, black-and-white designs produced algorithmically by Nees on the newly introduced Zuse Graphomat Z64 plotter. In April of that same year, A. Michael Noll of Bell Labs exhibited his own computer-generated graphic art at the Howard Wise Gallery in New York City (with Bela Julesz); and the world's third such exhibition was at the Galerie Wendelin Niedlich in Stuttgart in November of 1965, with algorithmically-generated Zuse Graphomat Z64 plots by both Nake and Nees (Dreher 2011).

Moreover, the work of these adherents of the Stuttgart School was from the beginning both interdisciplinary, involving (before the term became fashionable) philosophers, mathematicians, and artists, and also relatively mature in conception: identifying the algorithm with artistic style,

1 With the understanding that the following is a simplified version of a highly complex process, it can be said that any artist with a recognizable style has developed certain patterns of working, and to which patterns the term "algorithmic" can be meaningfully applied in much the same way that other terms from computer science-e.g., "multitasking" — have found broader usage. To the extent, furthermore, that these patterns of working impart a characteristic treatment to the artist's productions - the aforementioned "style" - this latter term can also be said to imply an algorithmic tendency, and vice versa. Finally, it should be noted that an artist's style and, therefore, his or her algorithmic tendencies are typically never more on display than in a closely related series of pieces, and this because the artist's core technique can be discerned amidst systematic or random variations in the source material. 
they produced works in series illustrating, as with Monet's series of paintings of the facade of the Rouen cathedral, not only the possible variations resulting from systematic or random changes to an algorithm's parameters, but also the nature of the core algorithm itself. All of this, furthermore, was accomplished and promulgated without prejudice to the possibility of some more traditional sources of inspiration, as with Nake's now iconic 1965 "Homage to Paul Klee" (Figure 1) in the collection of the Victoria and Albert Museum.

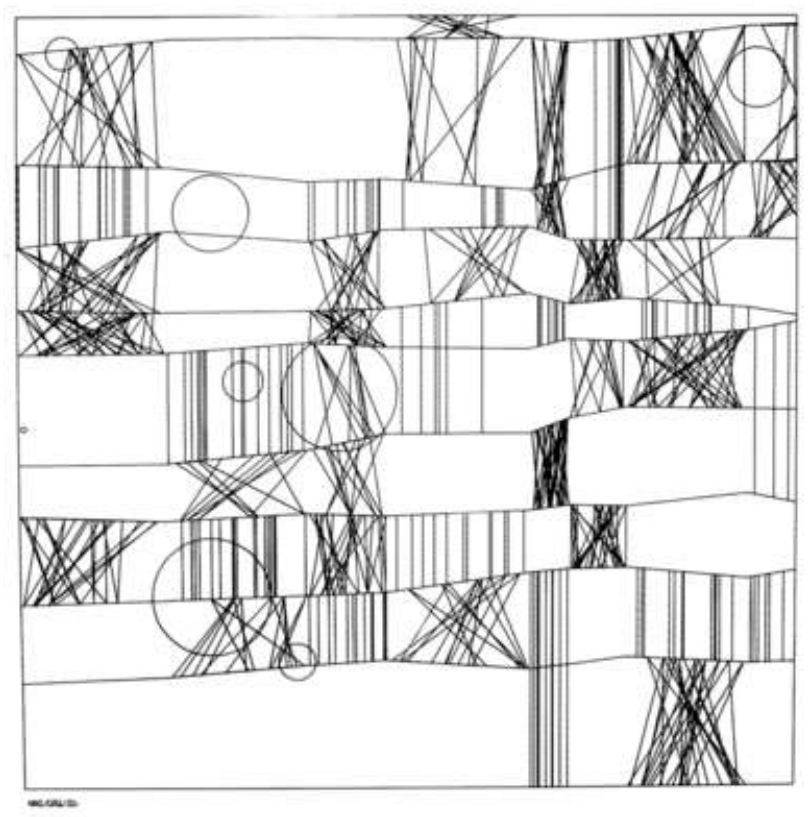

Figure 1. Homage to Paul Klee by Frieder Nake, 1965. Screenprint on paper, $49.2 \mathrm{~cm} \times 49.2 \mathrm{~cm}$. Victoria and Albert Museum. (C) Frieder Nake and used by permission.

Nake summarized his work with the algorithm in 1974 with a complete book on the subjectÄsthetik als Informationsverarbeitung (Aesthetics as Information Processing, Nake 1974) —and now, in his 80th year, has happily continued up to the present day to combine his academic career with his role as artist and algorithmic evangelist (Nake 2005, 2014, 2015, 2016). The following interview with Nake was conducted via email by artist/technologist G. W. Smith.

\section{The Interview}

GWS:

So now, Frieder-only 50 years after you and the other pioneers of computer art began using the term!- -we find that the "algorithm" has become a hot topic in techno-art circles, and in particular the DNN (deep neural network) and its close CNN (convolutional neural network) and GAN (generative adversarial network) relatives, and we hence feel compelled to ask the following questions: first, what have been your thoughts (and feelings) as you have watched all of this unfold over the last fifty years; second, what has been missed, and/or, have there been any surprises for you, i.e., despite the fact that you yourself are a visionary computer scientist, is it not astonishing that there is now an algorithm which can "capture" Van Gogh's style and apply it to an arbitrary photograph (Gatys et al. 2015); and third, where do things go from here?

FN:

When in the mid-1960s those first drawings appeared on walls of some galleries, and soon enough, in 1968, in the two remarkable international shows in, respectively, London (Cybernetic 
Serendipity: The Computer and the $\mathrm{Arts}^{2}$ ) and Zagreb (Tendencies 4: Computers and Visual Research), I thought-and was actually convinced - that something was happening that was funny, remarkable, but also destined to remain a marginal event only. I was proud of being a part of it. And, I tell you, I had reason to be. For from the first moment on, my stuff (and, perhaps, myself) was accepted by artists. Soon I got to know K.O. Götz, and he invited me to give a lecture at Kunstakademie Düsseldorf. And as a result of my second show in January/February 1966 in Darmstadt, Otto Beckmann wrote me from Vienna that we should cooperate on one of his projects.

Most likely, I overestimated the significance of what I was happy and lucky to experience. But it was great and tremendously inspiring. Now, jumping ahead several decades and, in the jump, passing my 1971 declaration that there should be no computer art (Nake 1971), we see that there are virtually no images any more that would not at least be touched to some minor degree by computer software. The image has generally become the digital image.

Such a statement is, of course, wrong. But it is correct at the same time. There are still dozens and hundreds of artists painting their canvases and preparing their printing plates. And there will be more of them forever. But the mainstream, often boring or nothing but commercial, has become "digital". This word, I should hurry to correct: the digital form of coding the image is not the important aspect. Important is that image generation is now happening, to a minor or major extent, by algorithm. The algorithm is the essence of the Algorithmic Revolution that we are witnesses of. And the essence of the Algorithmic Revolution is that all processes of society are transformed into computable form. The impact of this deep algorithmic turn-over of everything in culture we know and cherish and love is still not really understood by the masses, not even by all the experts of various kinds who currently swim with the wave of digitization.

This is the point where I want to take up your remark and question concerning van Gogh's style! Yes, there are teams of young researchers who do fantastic work in approximating a painter's style. They establish intricate systems that use given material (images in our case), analyze it, and use results of such analyses to generate new images in the "style", as they claim, of van Gogh or some other artist. That's interesting work requiring computer power and some intelligence. And it is greatly rewarding because the press will jump on it, and the public will again discuss the non-question of "who is the artist", and "is the computer an artist". It is, of course, not, and despite the nice success of such research, it has little to do with "art". Who, as an artist, would seriously copy some other artist's style? Who believes that style can be peeled off a painting? What we see in such fantastic projects is, of course, one necessary attempt at reducing some dead artist's work habits into computable form. That's difficult enough as a technical exercise. But it is not more than this.

Where do things go from here? They will go, on one hand, into the flat lands of ordinary mass culture. And they will appear as breathtaking new expressions that take as their subject matter the horrors of computability.

GWS:

Bense's information-intensive approach to aesthetics-and indeed, his preference for that term instead of "art" — clearly reflects a desire on his part to recognize within the art-making process an element of cool rationality. In your presentation to the "Art That Makes Itself" symposium (Nake 2015), you in turn specifically connect Bense's tendency in this direction with his goal of countering Hitler's raw emotional appeal; and as your very last remark in your three-part video interview with the Generative Art Science and Technology Journal (Nake 2005), you note that Bense was a "radical atheist", and with the implication that this was a further outgrowth of the rationalism which he hoped would shield society from future Hitlers. With an infinite degree of compassion, therefore, for Bense's motivations

2 In her introduction to the catalog for Cybernetic Serendipity (Reichardt 1968), curator Jasia Reichardt credits Max Bense with the idea for the exhibition. 
in espousing atheism, and without the slightest suggestion, furthermore, that the following remarks reflect a desire to return to a society in thrall to an unseen male deity, can we not-in addition to the rationality which it represents-also interpret the vitality of the algorithm as restoring some element of faith and hope in a benign universe? I refer, in the first place, to the fact that there is starting to be some organized resistance within academia (Nagel 2012) to the idea that it is only a matter of time before a purely reductive science (and note my emphasis on "reductive" as opposed to "science") will have been able to "explain everything" - and with the alternative being a science that admits the possibility of a synthetic, if not in fact creative, principle at work within the universe; and I refer, in the second place, to a concept which must inevitably arise in connection with that of the algorithm: emergence, or emergent phenomenon, i.e., the uncanny ability of relatively simple systems to exhibit relatively sophisticated behaviors. The $\mathrm{CNN}$, for example, is a relatively simple algorithm when compared with, say, a mathematical model of the atmosphere, and hence its ability to be deployed by non-technical individuals on personal computer systems; but again—as with the above Van Gogh style example—must we not be astounded by its capabilities? Your thoughts, please.

FN:

That's a lot and it is heavy. Let me try to first take up the reductive science aspect. Science in my view is, and must always be, reductive. Scientists try to understand "the whole". But the whole we can only have in parts. The scientific method—as we have become familiar with it—is a success story in taking as its subject matter an isolated aspect of the world, replacing it by a formal model (mathematical to a large extent), and re-interpreting results from dealing with the model in the context of the original aspect. But what science finds out are always statements about the model. For many practical issues, that's good enough to build a machine or other systems.

Newton did not understand nature. But he prepared the ground for the world of mechanical/ energetic machines. We replace the natural by the artificial. But the artificial is so powerful that we believe we understand the natural.

Yes, we are astounded by what models run on computers are capable of producing. However, our awe should not be accredited to the computer/software system, but to the human researchers and engineers who were creative enough to bring that about. And even if the engineers successfully explain the operations of their model to us, there may be emergent behavior that goes beyond the reach of the model. We call this "emergence", and tend to believe that emerging phenomena are totally new. They are not. They were implicit in the model's computational implementation.

Algorithms, even if they are of a rather basic character, show behaviors that we did not predict or even could not have predicted. But this is not a statement about a necessary characteristic of algorithms. We are in principle able to list all explicit behaviors of a given algorithm. But pragmatically, we don't do it. We rather wait and see. As the semiotic engine, the computer is always good for a surprise.

\section{GWS:}

Inasmuch as art is our ultimate subject, and inasmuch as there is a sense which hovers about you that something must be left unsaid—this in accordance with Yeats' statement that "Man can embody truth but he cannot know it" - how appropriate it is, first, that you decided early in your career to pay tribute to one of your artistic forebears; second, that said artist was Paul Klee, one of the most obviously "algorithmic" of the early modern artists (e.g., "I will create a marvelous painting with nothing but tiny colored squares and triangles"), but also one of the most enigmatic and mysterious; and third, that your own tribute to him (said to have been inspired by Highway and Byways, but I think also Castle and Sun (Figure 2)) is so evocative! By way of sneaking up on this subject, could you first acquaint us with your own early exposure to modern art in general and Klee in particular-and could you then go on from there to discuss Klee as an influence? 

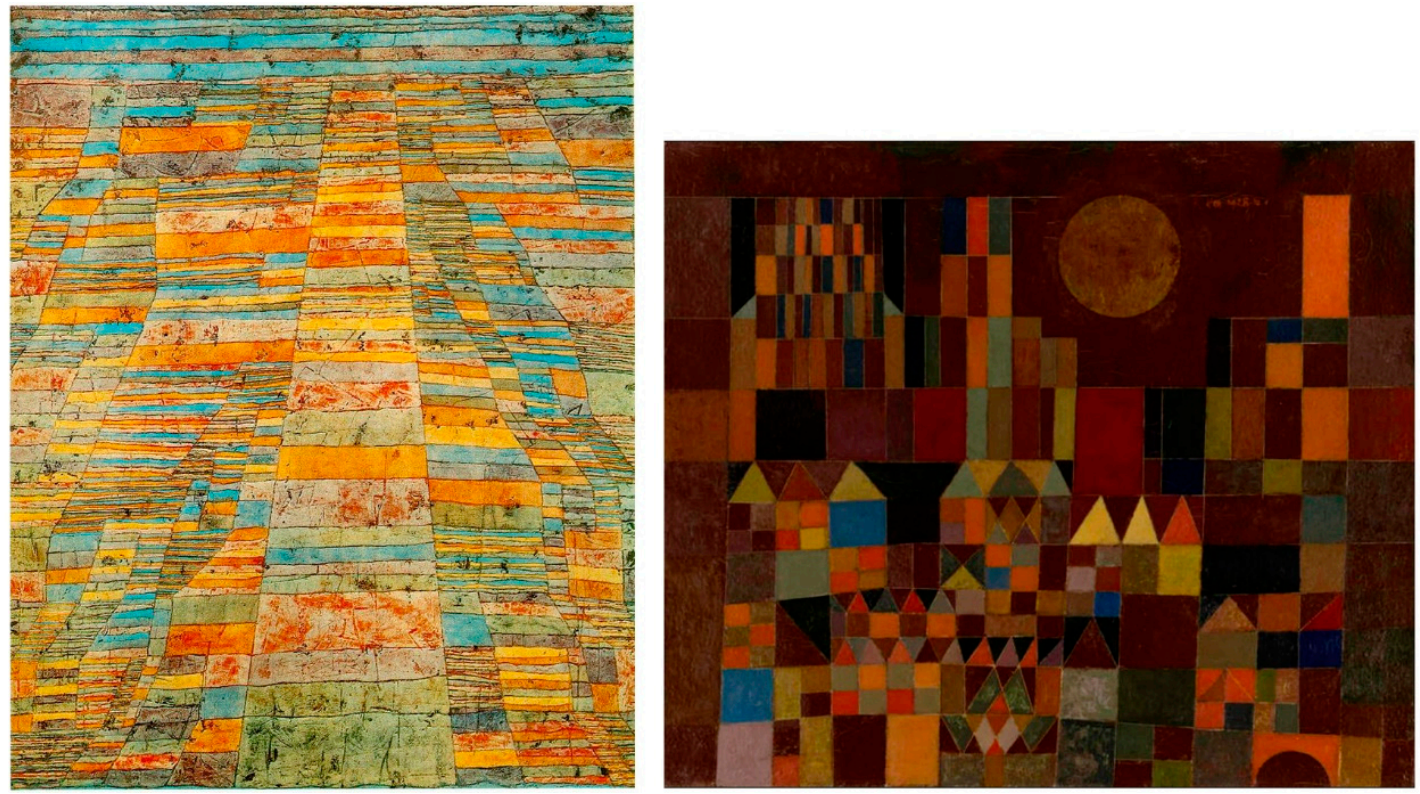

Figure 2. Highway and Byways by Paul Klee, 1929. Right: Castle and Sun by Paul Klee, 1928. Public domain images.

FN:

What a marvelous exposure, what an inspiring question! The way you characterize Paul Klee is the nicest and, at the same time, most enlightened that I may have encountered.

We are in 1965, and I possess a small little booklet of drawings by Klee. They are in black and white only, and I flip through the pages of that small collection. If I remember correctly, I felt grabbed by his drawings, and tried to analyze them in detail. Not in a technical way did I try to analyze them, but in my head. My thoughts circled around: this is so simple and basic that I must be able to program it, but, at the same time, my brain told me that any such attempt will be bound to fail. For Klee's lines are his lines, and before I will be able to simulate the stroke of his hand by algorithm, I will be doing something totally different from that which I have in mind. It will be of the utmost stupidity. In other words—so my thinking went—would it not be totally uninteresting and stupid to even try and simulate his stroke by algorithm?

And, of course, the next thought was, away from Klee's actual command of the physical line, his composition of small little elements that always in a way so surprisingly rich and light-heartedly massed up to sceneries that did not depict any real scene but that nonetheless, each one of them, could clearly be depictions. As you know, he told us so convincingly (in his twentieth century) that art does not reproduce the visible, rather it makes visible (about 1920).

Now here I was, and I had available a computer, and a drawing automaton, and I knew how to write algorithms for the computer, what else should I do but take up Klee's maxim about the invisible that should be made visible! (See the difference to the current style simulators?) So Klee during those months of August and September, 1965, became my source of inspiration.

But you have asked me about my exposure to modern art in general. I cannot answer this question in the same way that, perhaps, Michael Noll might be able to: well, my parents took me to MoMA on Sundays. ${ }^{3}$ Instead, I went to galleries in Stuttgart that were showing contemporary art. I did not know whether I liked what I saw or disliked it. I found it interesting. Often, I did find it more than this. I stood there, studying the painting. The nice Impressionist paintings in the Stuttgart Staatsgalerie

3 As noted in the introduction, Nake's fellow algorist Michael Noll exhibited his work in Manhattan, and he was in fact born in Newark and might very well have visited MOMA with his parents. 
were nice to look at. But I did not study them, I just liked them. What attracted me was definitely different from what they had shown us in high school. But one day in school, our teacher of fine art started talking about what he liked and, obviously, had been in immediate touch with. The teacher read wonderfully absurd texts to us, told stories about those artists, and also showed their pictures. It was Berlin Dada. It became a revelation. A sensation. Yes, Picasso was there. The Blue Period. That was melancholic. The cubist stuff? Braque's guitars were great. But Picasso's shook up girls? They were not sexy. Mondrian! That was also fantastic. Pollock! Even more. But the Dadaists were a different story. And they were against the war. And against the petit bourgeois. And then Paul Klee ... He gained a hidden influence on me. I don't think I discussed that with my friends who were studying painting at the fine arts school.

I became proud about my drawing "13/9/65 Nr. 2", as I called it. When in 1966 Carl Laszlo came to Stuttgart from Basel and invited me to produce a series of similar graphics that he wanted to add to a special edition of 200 copies of his Panderma magazine, I did it, was proud, did not take any money, and now called the first and original drawing "Homage to Paul Klee". A bit later, we produced a screenprint of 40 copies, with a few of them in white or green on pink paper (currently shown at the DAM Gallery in Berlin).

To finish this, let me add that in 2004 I did an interactive version of the algorithm. Together with Matthias Krauss and Susan Grabowski, we did a round bar table that has a screen and two pads. Two persons can manipulate the displayed drawing in various ways. The moving image is simultaneously projected onto the wall. It was fun and attracted quite a bit of attention in Kunsthalle Bremen and ZKM in Karlsruhe, and at other occasions later.

And, perhaps, I should add that I was invited to contribute in 2008 to an exhibition at Zentrum Paul Klee in Bern, Switzerland. I guess this was a recognition of some kind.

Acknowledgments: The author would like to thank Frieder Nake, and all of his fellow algorists, for their pioneering work.

Conflicts of Interest: The author declares no conflict of interest.

\section{References}

Dreher, Thomas. 2011. History of Computer Art. Available online: http://iasl.uni-muenchen.de/links/GCA-III.2e. html\#Computergrafik (accessed on 16 February 2019).

Gatys, Leon A., Alexander S. Ecker, and Matthias Bethge. 2015. A Neural Algorithm of Artistic Style. arXiv. Available online: https://arxiv.org/pdf/1508.06576.pdf (accessed on 16 February 2019).

Nagel, Thomas. 2012. Mind and Cosmos: Why the Materialist Neo-Darwinian Conception of Nature is Almost Certainly False. Oxford: Oxford University Press.

Nake, Frieder. 1971. There Should Be No Computer Art. Page, the Bulletin of the Computer Arts Society 18: 1-2.

Nake, Frieder. 1974. Ästhetik als Informationsverarbeitung. Vienna: Springer.

Nake, Frieder. 2005. Interview with Frieder Nake. Generative Art Science and Technology Hard Journal. Available online: http://www.gasathj.com/tiki-read_article.php?articleId=50 (accessed on 16 February 2019).

Nake, Frieder. 2014. Eyeo Festival Presentation. Available online: https://vimeo.com/104315361 (accessed on 16 February 2019).

Nake, Frieder. 2015. Art That Makes Itself Symposium Presentation. Available online: https://www.youtube.com/ watch?v=ICOs_8pjOIc (accessed on 16 February 2019).

Nake, Frieder. 2016. The Algorithmic Art Manifesto. In Nevertheless. 17 Manifestos. Edited by Andrea Sick. Hamburg: Textem Verlag, pp. 67-70. Available online: http://17.manifestos.de/ (accessed on 16 February 2019).

Reichardt, Jasia. 1968. Cybernetic Serendipity: The Computer and the Arts. Studio International Special Issue. July. Available online: http://www.studiointernational.com/flipbookCyberneticSerendipity/ StudioInternationalCyberneticSerendipity-1968.html (accessed on 22 March 2018). 